\title{
Prevalence and Risk Factors of Gastrointestinal Parasite Infection in Goats in Sironko District, Eastern Uganda
}

\author{
Winnie Namutosi ${ }^{1}$, James Higenyi ${ }^{2, *}$, Elizabeth Kizito ${ }^{1}$, Micheal Omodo ${ }^{2}$ \\ ${ }^{1}$ Faculty of Science and Technology, Uganda Christian University. \\ ${ }^{2}$ Department of Animal Health, Ministry of Agriculture, Animal Industry and Fisheries, Entebbe, \\ Uganda.
}

*Corresponding author. $\square$ 153, Entebbe, Uganda @ higenyijames9@gmail.com

\begin{abstract}
This study investigated the prevalence and risk factors of gastrointestinal parasite (GIP) infections in goats in Sironko District. Randomly selected livestock farmers (28) were interviewed. Two hundred twenty (220) faecal and blood samples were analysed using laboratory techniques. The overall prevalence of GIP was 74.5 percent. Nematodes were the most prevalent $(61.8 \%)$. The level of GIP infections were; Eimeria (37.7\%), Haemonchus contortus (36.4\%), Trichostrongylus (43.6\%), Strongyloides (14.6\%), Strongyle (12.7\%), Nematodirus (0.9\%), Moneizia (14.55\%) and Fasciola $(11.82 \%)$. Further analysis showed high $(48.6 \%)$ anaemia in adult goats. The most significant risk factors were location of farm $(\mathrm{p}=0.001)$, production system $(\mathrm{p}=0.045)$ and frequency of deworming $(\mathrm{p}=0.023)$. It is concluded that there is a high prevalence of GIP linked with heavy infection in the area. Therefore, it is imperative to promote agricultural adaptation strategies that will strengthen the farmers' resilience.
\end{abstract}

Keywords: Gastrointestinal parasites, Goats, Risk factors, Resilience.

\section{Introduction}

Globally, goat production is an important component of the livestock sector that contributes to food and nutritional security, incomes and sustainable agriculture especially in developing countries (Solaiman, 2010, Thornton, 2010). In Uganda, the enterprise contributes significantly to the livelihoods of the marginalized small scale farmers in the rural and peri-urban areas with limited land (UBOS, 2018). It is estimated that 4.5 million households $(70.8 \%)$ in the country rear at least one kind of livestock (UBOS, 2018). However, the livelihoods of $48 \%$ small scale farmers largely depend on goat production for provision of socioeconomic values including food, a source of income and organic fertilizer for sustainable crop farming (Lapenga, 2009, Katali et al., 2015, UBOS, 2018). More importantly, the enterprise has proven to be the best means enable resilience of the vulnerable marginalized small scale communities against crop failures (Katali et al., 2015).

Despite the enormous contribution of goats to the livelihoods of the farming communities, present information indicates that gastrointestinal parasite infection is a major hindrance to the 
development of goat production in many parts of the world (Nganga, 2004, Negasi et al., 2012). The prevalence of gastrointestinal parasites is increasingly attributed to environmental changes, emerging anthelmintic résistance and herd management practices that favour parasite development (Martinez et al., 2015). The emerging climate change characterized by alternating rainfall patterns, floods and prolonged droughts resulting from global warming have contributed to spatial and temporal distribution and abundance of pests and diseases that impact on animal health (Martinez et al., 2015). There is unequivocal evidence that gastro intestinal parasitic infections pose a serious health risks limiting efficient production of livestock. This in turn results into under production and productivity due to increased morbidity and death (Sheikh, 2016, Nwosu et al., 2007). Bhat et al. (2011) reported decreased profitability of up to $15 \%$ and weight loss of up to $50 \%$ in goat production due gastrointestinal parasites. Though, clinical coccidiosis is of greater importance in young goats because of severe mortality of goats aged between four to ten weeks (RUIZ et al., 2010).

In Uganda, studies that have attempted to investigate the epidemiology of gastro intestinal parasitic infections (GIP) in small ruminants have largely concentrated on nematodes, though, grazing goat are invariably infected with several of gastrointestinal parasites. For instance, Nsereko et al. (2015) researched about nematodes and reported prevalence of $43 \%$ in goats while Magona and Musisi (2002) focused on strongyloidosis and revealed a significantly high prevalence of $73.3 \%$. These findings have not been explicit and provide limited information on the situation of gastrointestinal parasites infections in small ruminants, particularly the magnitude and extent of infection rate. Moreover, anecdotal evidence suggests that greater parts of marginalized small scale farming communities engaged in goat production suffer economic losses associated with gastrointestinal parasites infections. It is estimated that $21.5 \%$ of the small scale farmers engaged in goat production in Sironko district, Eastern Uganda frequently experience mortalities estimated at $40 \%$ due to gastrointestinal parasites infections (Anonymous report, 2015, UBOS, 2018). Notwithstanding, Uganda is extremely experiencing alternating rainfall patterns, floods and prolonged droughts which inevitably influence distribution and abundance of GIP in livestock production systems. As such, there is urgent need to understand the prevalence, distribution and risk factor of gastro intestinal parasites in goats to maximize on production and productivity. This case study was conducted to determine the prevalence, distribution pattern and risk factors associated with gastrointestinal parasites infections in goats in semi-arid areas in the Eastern Uganda.

\section{Materials and Methods}

A cross-sectional study was conducted in Sironko district in three administrative units, namely, Sironko, Bukholo and Bukiyi parishes. In the field survey, twenty eight (28) small holder livestock farmers randomly selected were interviewed using structured questionnaires to assess socio-demographic factors and risk factors including production related factors, management practices, among others which impact on the epidemiology of GIP infections in goats (Figure 1). 


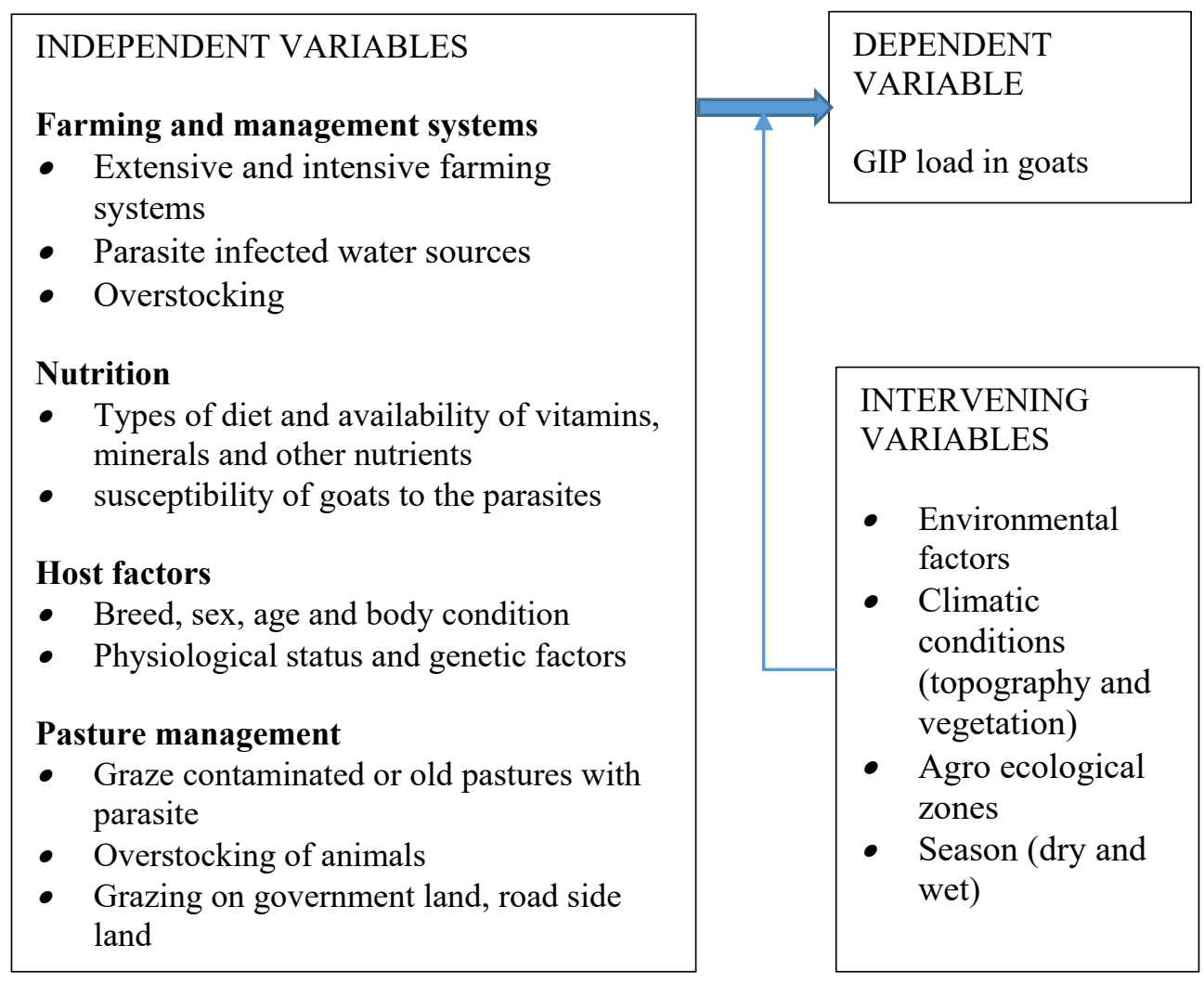

Figure 1. Conceptual framework for the study of GPI

In the laboratory, a total of two hundred and twenty (220) samples of faeces and whole blood with (EDTA) were collected from goats in the herds of small holder livestock farmers interviewed. Four goats were randomly selected, blood and faecal sample collected from each of them. Later presented for analysis using various laboratory techniques including faecal flotation, sedimentation, modified McMaster and microhaematochrit methods (MAFF, 1986, Hansen, 1994). Faecal floatation was used for detection of nematode, cestodes eggs and coccidia oocysts in the faeces. This method separates eggs from faecal material and concentrates them by means of flotation solutions (zinc sulfate and sodium chloride). Faecal sedimentation technique was used to detect trematodes eggs in the faeces because most of the trematodes eggs are relatively large and heavy compared to nematode eggs as such this technique concentrates them in sediment while modified McMaster method and microhaematocrit centrifuge method were used to determine egg count and packed cell volume (PCV) respectively. The severity, level or burden of GIP infection was evaluated through the mean PCV values and faecal egg counts (epg) to depict the level of anaemia in reference to the recommended normal range (Shivairo and Musala, 2002; Kramer, 2000; Duncan and Prasse, 1986).

Qualitative data collected from the field was coded; together with quantitative data from the laboratory was then transcribed into Microsoft excel (2007). Later exported to statistical package for social scientists (SPSS version 20) and STATA Data Analysis system version 14 for 
descriptive and inferential analyses. Descriptive analysis generated information which was represented in tables and graphs. The binomial test was used to analyse categorical data obtained from the laboratory. Multivariate regression analysis was performed to determine which factors influence the prevalence gastrointestinal parasites. The infection rate of each parasite species was calculated using the formula: $\mathrm{P}=\mathrm{d} / \mathrm{n} * 100$; where $\mathrm{d}$ is the number of animals affected (having a given parasite at that point in time) and $n=$ number of animals at examined at that point in time (Thrushfield, 1995).

\section{Findings}

In this study, majority of the respondents were females $(61 \%, n=17)$ with average age of 47 years. Most of respondents attained primary level education $(57.1 \%, \mathrm{n}=16)$ and majority of whom considered farming a full time employment $(92.9 \%, n=26)$ (Table 1).

Table 1. Respondents' Socio-demographic Characteristics

\begin{tabular}{llll}
\hline & Variables & Number & Percentage \\
\hline Location & Sironko & $28(10)$ & 35.7 \\
& Bukhulo & $28(10)$ & 35.7 \\
Age & Bukiyi & $28(8)$ & 28.6 \\
& Below 18 & 0 & 0 \\
$18-35$ & $(28) 6$ & 21.4 \\
& $35-45$ & $(28) 5$ & 17.9 \\
Above 45 & $(28) 17$ & 60.7 \\
Sex & & \\
Occupation & Male & $(28) 11$ & 39.3 \\
& Female & $(28) 17$ & 60.7 \\
Education level & Non salary & $(28) 26$ & 92.9 \\
& Salary & $(28) 2$ & 7.1 \\
& None & $(28) 3$ & 10.7 \\
& Primary & $(28) 16$ & 57.1 \\
& Secondary & $(28) 7$ & 25.0 \\
& Diploma & $(28) 1$ & 3.6 \\
& Degree & $(28) 1$ & 3.6 \\
\hline
\end{tabular}

Mean of age $=47$, Mode $=60$, Min age $=18$, Maximum Age $=74$

\section{Prevalence of gastrointestinal parasites infections}

The most abundant gastrointestinal parasites were nematode with prevalence rate of $61.82 \%$ $(\mathrm{n}=68)$. Other common GIP include the coccidian $(32.73 \%, \mathrm{n}=36)$, cestodes $(14.55 \%, \mathrm{n}=$ 16) and trematodes $(11.82 \%, \mathrm{n}=13)$. The overall prevalence of GIP infections were high (74.5\%, $\mathrm{n}=85)$. The summary of GIP Mean egg/ oocysts counts per gram indicated that goats were heavily infested with nematode parasites (Trichostrongylus spp) at $43.64 \%$ as indicated in Table 2 and 3 . 
Table 2. Prevalence of Gastrointestinal Parasites in Goats by Location

\begin{tabular}{|c|c|c|c|c|}
\hline Location & Species & $\begin{array}{l}\text { No. of animals } \\
\text { examined }\end{array}$ & $\begin{array}{l}\text { No. of affected } \\
\text { animals }\end{array}$ & $\begin{array}{l}\text { Prevalence } \\
(\%)\end{array}$ \\
\hline \multirow[t]{8}{*}{ Sironko } & Eimeria spp & 40 & 10 & 25 \\
\hline & Haemonchus contortus & 40 & 15 & 37.5 \\
\hline & Trichostrongylus spp & 40 & 18 & 45 \\
\hline & Strongyloides spp & 40 & 5 & 12.5 \\
\hline & Strongyle spp & 40 & 8 & 20 \\
\hline & Nematodirus spp & 40 & 1 & 2.5 \\
\hline & Moneizia spp & 40 & 6 & 15 \\
\hline & Fasciola spp & 40 & 8 & 20 \\
\hline \multirow[t]{8}{*}{ Bukholo } & Eimeria spp & 40 & 14 & 35 \\
\hline & Haemonchus contortus & 40 & 13 & 32.5 \\
\hline & Trichostrongylus spp & 40 & 16 & 40 \\
\hline & Strongyloides spp & 40 & 8 & 20 \\
\hline & Strongyle spp & 40 & 3 & 7.5 \\
\hline & Nematodirus spp & 40 & 0 & 0 \\
\hline & Moneizia spp & 40 & 3 & 5 \\
\hline & Fasciola spp & 40 & 5 & 12.5 \\
\hline \multirow[t]{8}{*}{ Bukiyi } & Eimeria spp & 30 & 11 & 36.67 \\
\hline & Haemonchus contortus & 30 & 12 & 40 \\
\hline & Trichostrongylus spp & 30 & 14 & 46.67 \\
\hline & Strongyloides spp & 30 & 3 & 10 \\
\hline & Strongyle spp & 30 & 3 & 10 \\
\hline & Nematodirus spp & 30 & 0 & 0 \\
\hline & Moneizia spp & 30 & 8 & 26.67 \\
\hline & Fasciola spp & 30 & 0 & 0 \\
\hline Overall & GIP & 110 & 82 & 74.5 \\
\hline
\end{tabular}

Table 3. Mean egg/oocysts per gram of gastrointestinal parasites

\begin{tabular}{llllll}
\hline Parasite spp & Prevalence & Mean EPG & Std. & $\begin{array}{l}\text { Min- Max } \\
\text { (epg) }\end{array}$ & $\begin{array}{l}\text { Recommended } \\
\text { max epg }\end{array}$ \\
\hline Eimeria spp & 37.73 & 155.45 & 484.03 & $0-4000$ & $<300$ \\
Haemonchus contortus & 36.36 & 132.73 & 250.18 & $0-1150$ & $<200$ \\
Trichostrongylus spp & 43.64 & 404.09 & 980.41 & $0-7100$ & $<200$ \\
Strongyloides spp & 14.55 & 45 & 131.67 & $0-800$ & $<200$ \\
Strongyle spp & 12.73 & 20.91 & 63.67 & $0-350$ & $<200$ \\
Nematodirus spp & 0.91 & 0.91 & 9.54 & $0-100$ & $<100$ \\
Moneizia spp & 14.55 & 30 & 150.12 & $0-1450$ & $<100$ \\
Fasciola spp & 11.82 & 43.18 & 291.51 & $0-3000$ & $<50$ \\
\hline
\end{tabular}

The results also indicated the prevalence of various gastrointestinal parasite infections in different age groups. Young goats had a high prevalence of Eimeria spp $(46.2 \%, \mathrm{n}=12)$, moneizia $\operatorname{spp}(15.4 \%, \mathrm{n}=4)$ and Nematodirus spp $(3.9 \%, \mathrm{n}=2)$ than adults goats. Though, in adult goats the prevalence of Trichostrongylus spp was higher with (45.3\%, $\mathrm{n}=34)$, Haemonchus contortus $(38.1 \%$, 
$\mathrm{n}=32)$, Strongloides $\operatorname{spp}(15.5 \%, \mathrm{n}=13)$, Strongyle $\operatorname{spp}(14.3 \%, \mathrm{n}=12)$ and Fasciola $\operatorname{spp}(11.9 \%, \mathrm{n}=10)$ than the young goats (Figure 2).

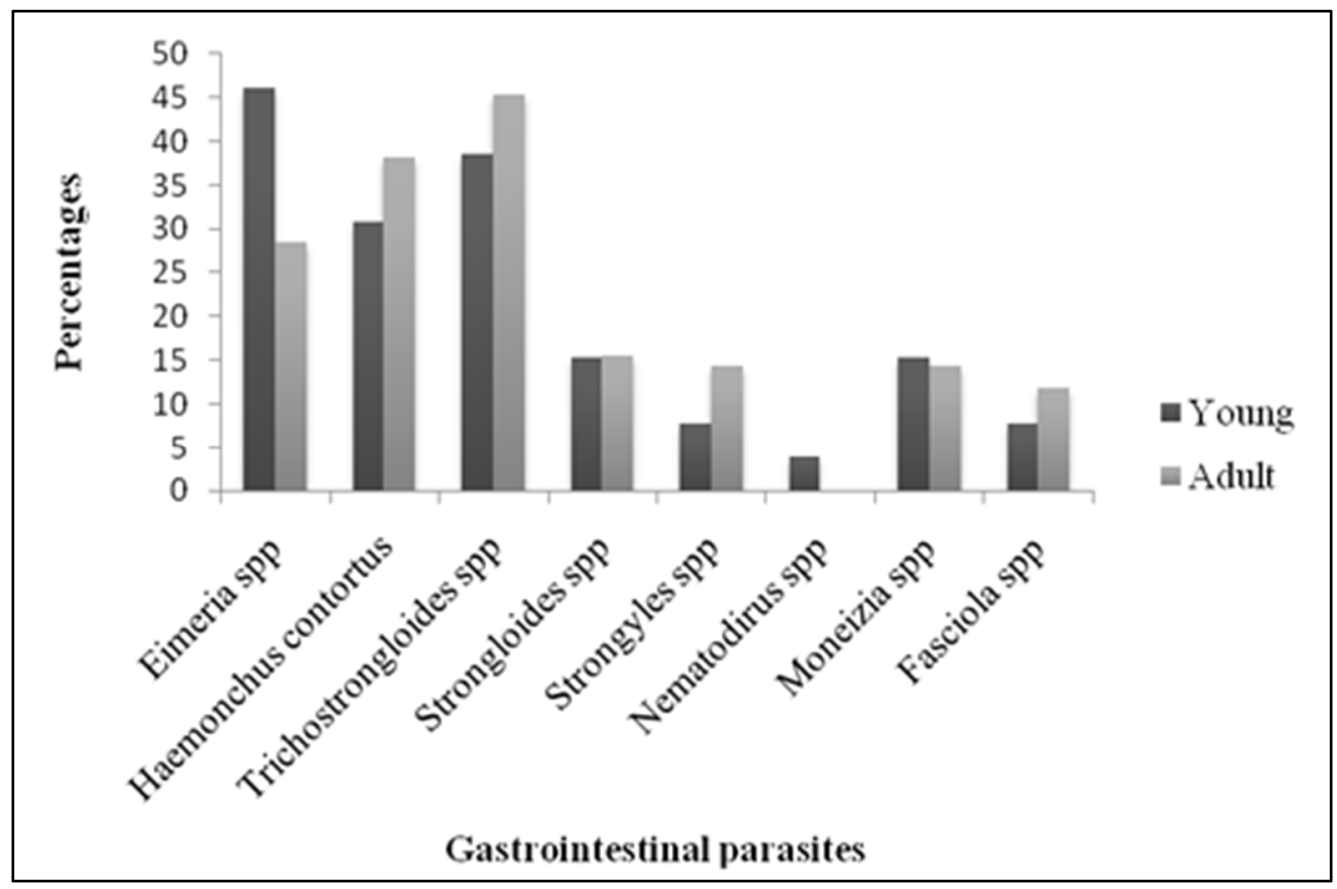

Figure 2. Prevalence of gastrointestinal parasites infection by age

The study revealed PCV mean values of $22.50 \%$ and $21.51 \%$ for young and adults respectively. More importantly, the higher percentage of anaemic goats were adults $(48.6 \%, \mathrm{n}=35)$ than young ones $(45.5 \%, \mathrm{n}=10)$ (Table 4$)$.

Table 4. Results of PCV mean by Age Group

\begin{tabular}{lcclll}
\hline Age group & PCV $(20-30 \%)$ & PCV $(<20 \%)$ & Mean & Std. Deviation & Std. Error \\
\hline Young (22) & $12(22) 54.5$ & $10(22) 45.5$ & 22.50 & 6.139 & 1.309 \\
Adult (72) & $37(72) 51.4$ & $35(72) 48.6$ & 21.51 & 5.624 & 0.591 \\
Total (94) & $49(94) 52.1$ & $45(94) 47.9$ & 21.74 & 5.730 & 0.591 \\
\hline
\end{tabular}

Trichostrongylus spp was the most abundant gastrointestinal parasite and highly distributed among different administrative units; Sironko (45.0\%, $n=18)$, Bukhulo $(40.0 \%, n=16)$ and Bukiyi $(46.7 \%, \mathrm{n}=14)$. In addition, Eimeria spp was highly distributed in Bukiyi parish $(36.7 \%, \mathrm{n}=11)$ than in Bukhulo $(25.0 \%, \mathrm{n}=10)$ and Sironko $(35.0 \%, \mathrm{n}=14)$ as shown in Figure 3. 


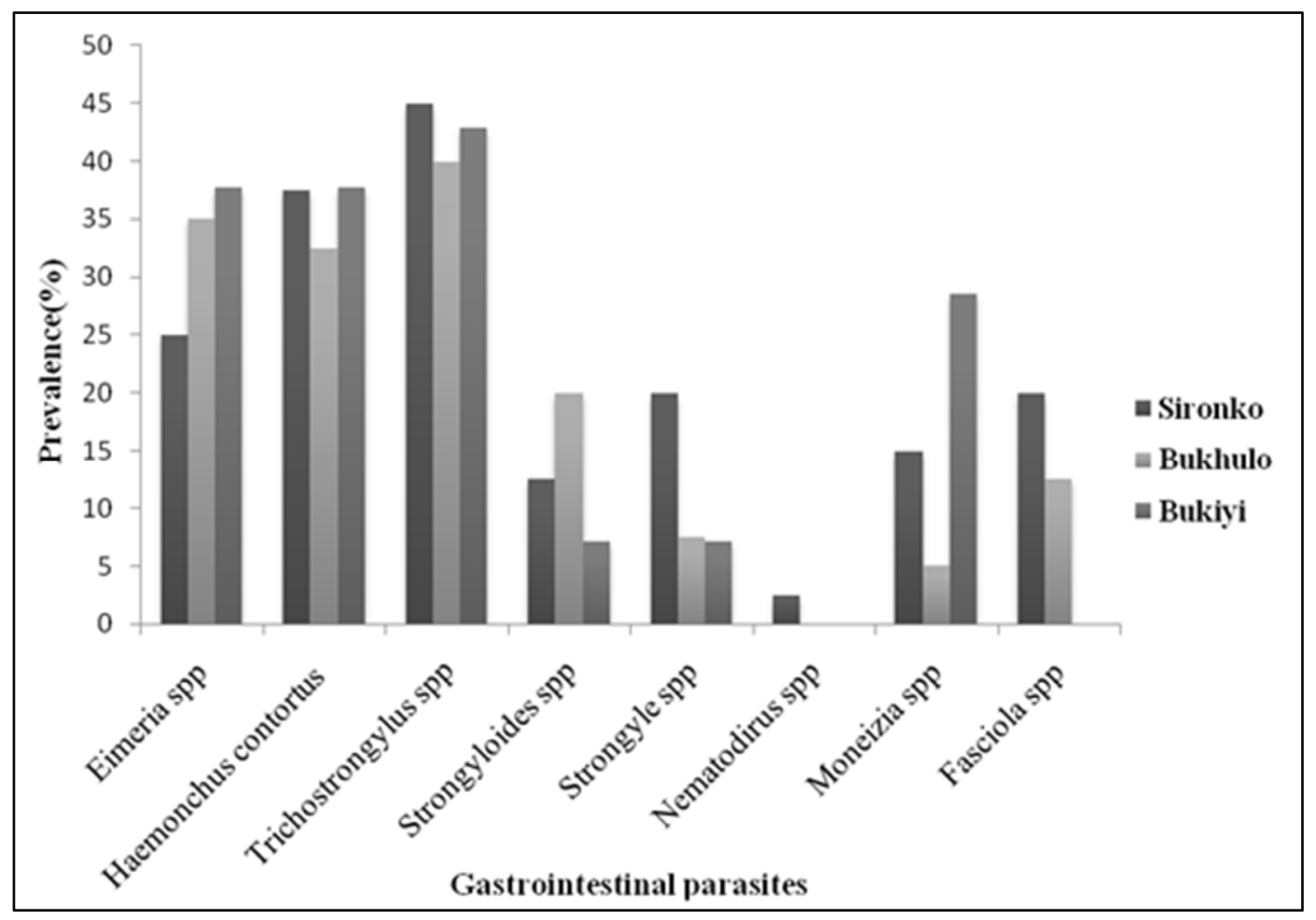

Figure 3. Distribution pattern of the GIP species in Sironko District.

The regression model showed that the most important factors which strongly influenced the increasingly high level burden of GIP were; location of farm $(\mathrm{P}=0.001)$, frequency of deworming $(\mathrm{P}=0.023)$ and production systems $(\mathrm{P}=0.045)$ (Table5).

Table 5. Prediction of risk factors for GPI in goats

\begin{tabular}{lllllll}
\hline Equation & Obs & Parms & RMSE & "R-sq" & F & P \\
\hline GIP & 8 & 6 & 2.695153 & 0.8541 & 0.7564112 & 0.0014 \\
GIP & Coef. & Std. Err. & T & P>t & [95\% Conf. & Interval] \\
Location & 0.0092981 & 0026071 & 3.57 & 0.001 & 0039391 & .0146571 \\
Breed type & -1.131926 & 2.728575 & -0.41 & 0.719 & -12.87204 & 10.60819 \\
Production system & 4.742304 & 2.914206 & 1.63 & 0.045 & 17.28112 & 7.796511 \\
Feeding system & 4.704485 & 4.697007 & 1.00 & 0.422 & -15.50511 & 24.91408 \\
Water source & 0.0976253 & 0.5179978 & -0.19 & 0.868 & -2.32639 & 2.131139 \\
Frequency of deworming & 0.0949868 & 0.8645621 & 0.11 & 0.023 & 3.624924 & 3.814897 \\
Age group of goats & 1.5 & 2.223611 & 0.67 & 0.525 & -3.940979 & 6.940979 \\
Farmers' education level & 1.232143 & .8883816 & 1.39 & 0.224 & -1.051515 & 3.515801 \\
Sex of farmers & 1.089286 & 2.235711 & 0.49 & 0.647 & -4.657793 & 6.836365 \\
cons & 21.2489 & 16.18086 & 1.31 & 0.320 & -48.37172 & 90.86952 \\
\hline
\end{tabular}


The result also indicate three production system, namely; tethering $(72.4 \%, \mathrm{n}=21)$; semiintensive $(17.2 \%, \mathrm{n}=5)$ and intensively $(6.9 \%, \mathrm{n}=2)$. The most common feeding systems for goats were; browse and supplement $(62.1 \%, \mathrm{n}=17)$; cut and carry $(27.6 \%, \mathrm{n}=8)$ and herding $(10.7 \%, \mathrm{n}=3)$. The results also indicated that majority of the respondents dewormed their goats at intervals of $2-3$ months $(42.9 \%, \mathrm{n}=12)$ and frequently used albendazole $(35.7 \%, \mathrm{n}=10)$ (Figure 4).

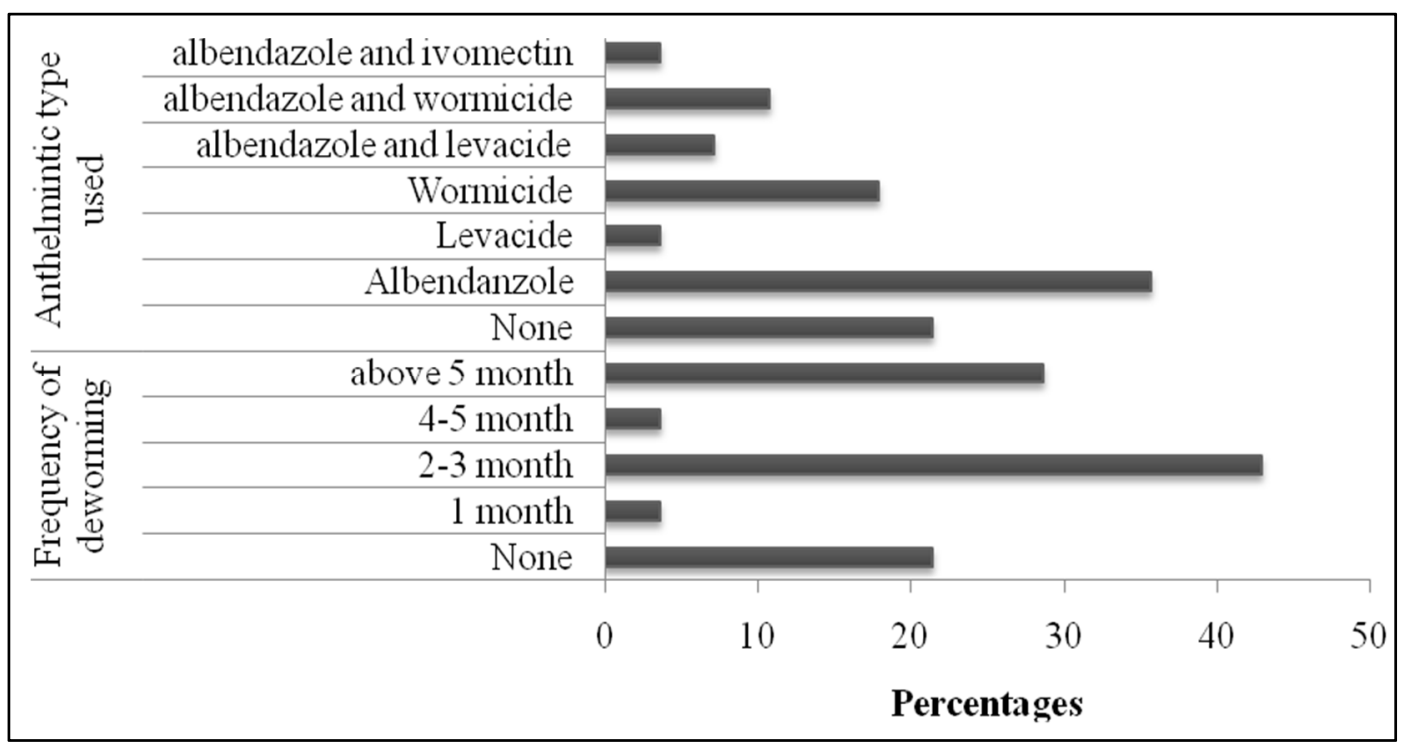

Figure 4. Anthelmintic type used and frequency of deworming

The results also showed that the main challenges for the goat farmers were; diseases and inadequate water $37.9 \%$ together with scarcity of feeds $24.1 \%$ (Figure 5).

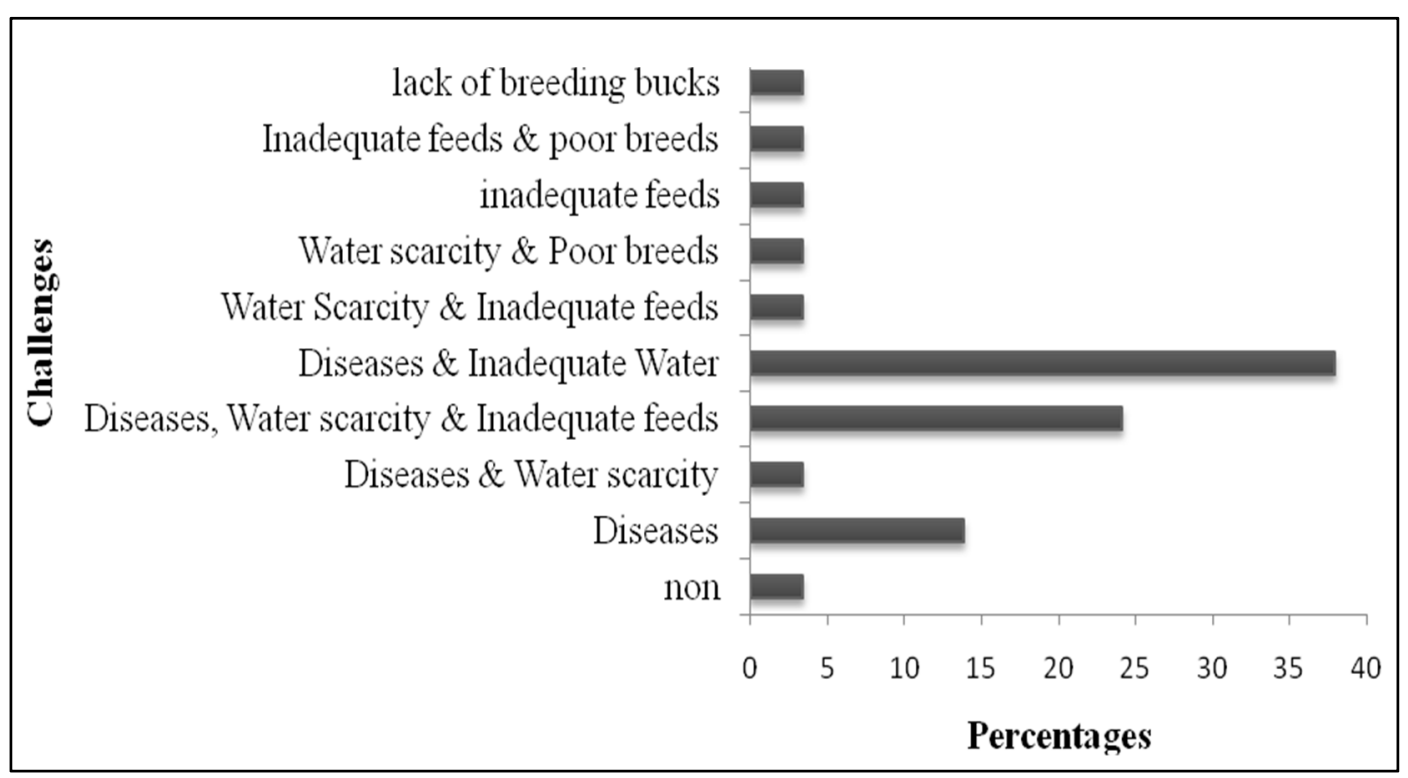

Figure 5. Challenges faced by goat farmers 
Interestingly, the farmers' main survival or coping strategy was treatment and procurement of forage at $17.2 \%$ together with procurement of water $6.9 \%$ (Figure 6 ).

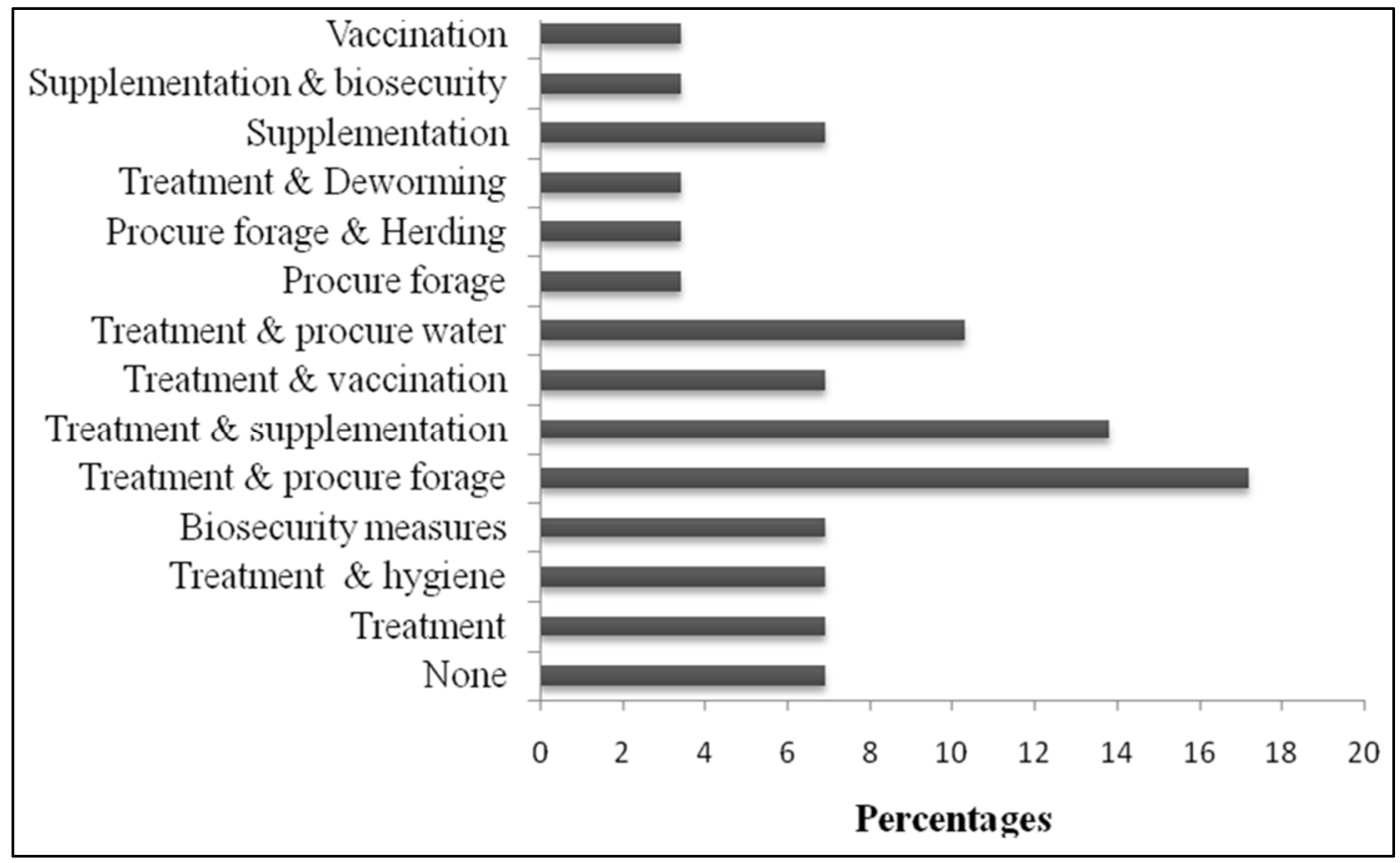

Figure 6. Coping strategies used by farmers

\section{Discussions}

Gastrointestinal parasite infections is increasingly becoming a serious threat to the health of small ruminants particularly in the marginalized small scale farming communities in the under developed countries including Uganda. This in turn has led to significant economic losses attributed to under production, morbidity and death. The semi-arid areas of Eastern Uganda are extremely affected by the sweeping climate change of alternating rainfall patterns, floods and prolonged drought. As such, understanding the level of infestation and distribution of gastrointestinal parasite infections is important for a profitable and sustainable goat production. Largely, this study was the first of its kind in Uganda to investigate the prevalence and risk factors of gastrointestinal parasite infections in goats particularly districts in highland areas. The results showed a high prevalence of gastrointestinal parasites particularly nematode species. This finding was in agreement with the study by Singhi (2013), who reported $75 \%$ of GIP infections. The results are also consistent with the findings of Meingi et al. (2001) in Kenya, who reported prevalence of $62 \%$ for nematodes. Similarly, Nsereko et al. (2015) reported a prevalence of nematodes at $43 \%$.

The study indicated that location of the farms, production system and management practices were the main risk factor influencing the abundance and distribution of gastrointestinal parasites in goats. Regarding location of the farm, it was evident that helminthes and protozoa were relatively abundant on farms in Bukiyi parish which is located on high altitude. This is consistent with contemporary information which indicates that goat farms located on higher 
altitude have a higher prevalence of gastrointestinal parasite infections because of the favourable climatic conditions for the development of the free-living stages of the GIP (Singh et al., 2017). Further, it's supported by Kantzoura et al. (2012), who revealed that location of the farm was a risk factor for helminthes infections in small ruminants. In the same way, Dagnachew et al. (2011) found differences in distribution of GIPs between highlands and lowlands agro ecological zones; highest prevalence of helminthosis especially strongyles in lowlands than mountains.

Equally important was production system, tethering system was observed predominant goat production system; which is largely recognized for exposing goat to GIP infections through contaminated pastures especially in the wet season. This was consistent with Nsereko et al. (2015), who emphasized that tethering of goats results into increased possibility of picking nematode larvae because they feed on little vegetation thus pick the parasites from the ground. More importantly, management practices particularly frequency of deworming partly contributed to the observed prevalence of GIP infection. For instance, it was evident that a modest proportion of study indicated that frequency of deworming was a strong determinant influencing GIP infections. This is consistent with other studies by Nwosu et al. (2007) and Akhtar et al. (2000) which emphasized poor management practice and inadequate health control measures as predisposing factors for increased GIP infections. On the contrary, GIP infections could be associated with prolonged use of a single type of anthelmintic (Albendazole) which results into selection and evolution of resistant strains. This was supported by Nsereko et al. 2015, Katali et al. 2015 and Nabukenya et al. 2014. More often goats treated with albendazole recommence pasture contamination with infective stages of the parasite sooner than those treated with levamisole or ivermectin (Iglesias et al., 2006).

The study also established that goats are heavily infested with Trichostrongylus spp across all the administrative units. This concurs with studies by Olorunfemi (2015), who reported high prevalence of $16.1 \%$ in goats. The high prevalence of Trichostrongylus spp is attributed to the production system which is mainly tethering together with frequency of deworming. This is consistent with findings of Nsereko et al. (2015) and Beveridge (1989). Nonetheless, other major nematode parasites included; Strongyloides, Nematodirus and Strongyle which had low prevalence while Haemonchus was modest. This was in agreement with other studies by Jiregna (2018) and Babjak (2017), who reported prevalence of Strongyloides of 8.33\% in Ethiopia and Nematodirus spp of 3.98\% respectively; contrary to a study by Magona (1999), who reported a high prevalence of strongylodosis at $73.3 \%$ in goats. The observed low prevalence of some nematode species is more likely to be associated with deworming using different types of anthelmintics which enhances efficaciousness of drugs and reduces anthelmintic resistance. This is consistent with studies by Katali (2015), who observed that regular use of anthelmintic drugs especially alternating albendazole and wormicide reduces the egg per gram counts of the parasites.

The study further found a modest prevalence of Eimeria spp. This was contrary to the findings by Zvinorova (2016) who reported prevalence of $43 \%$. The modest prevalence of Eimeria spp is attributed to production system, management practices and host attributes. It was observed that some respondents practiced intensive production systems, which inevitably predisposes animals to poor hygiene, contaminated feed or water and stress. This was in agreement with findings of Khodakaram (2017), who noted that variation in prevalence of Eimeria spp infection and distribution was attributed to the differences in management and hygienic conditions, temperature, agro ecology, climate, weather conditions like wet conditions and the immunity of the goat. Another study by Nwigwe et al. (2016) re-iterated that increased rate of protozoa infections is an outcome of overgrazing, overstocking and poor hygiene practices. 
Equally important was Fasciola spp which was detected on farms in two administrative units; Sironko and Bukholo though with low prevalence. This was contrary to findings by Lisa et al. (2014), who reported a high prevalence of $68 \%$. The variation in occurrence of Fasciola spp among the administrative units is attributed to physical location of the farms. Bukhulo and Sironko are located on low altitude relative to Bukiyi as such conditions (temperature and rainfall) favour the development and hatching of Fasciola spp. This argument is supported by Ratanapob et al. (2012), who recognized that different locations experience variations in temperature and rainfall patterns which influence parasite infective stages and severity of the parasite. This concurs with study by Kantzoura et al. (2011), who re-affirmed that altitude contributed to presence of Fasciola spp in small ruminants. Similarly, the results indicated a high prevalence of moneizia spp especially in high altitude areas of Bukiyi.

Furthermore, the severity of GIP infections was evaluated through determining the mean PCV values to depict the level of anaemia. Generally, most of the goats had their average PCV in the recommended normal range and a modest percentage of goats had low PCV which strongly suggested heavy infestation with GIP especially Eimeria spp, Haemonchus and Trichostrongylus spp. These protozoa and helminthes are recognized to lead to loss of blood resulting into moderate level of anaemia which was predominantly observed in adult goats. This could be explained by fact that adult goat are more often exposed to contaminated pasture than the young ones which predisposes them to GIP infections. Equally, the moderate level of anaemia partly re-affirms regular deworming. This was consistent with the findings by Shivairo and Musalia (2002), which re-iterated that the frequent anthelmintic usage over $83 \%$ in Baringo District of Kenya reduced anaemic level in goats to only $19.3 \%$ represented by PCV of less than $20 \%$.

\section{Conclusion}

The study has established a high prevalence of gastro intestinal parasite infections in goats; particularly Trichostrongylus, Haemonchus and Eimeria which is widely spread across the administrative units. This heavy infestation with helminthes and protozoa is highly linked to the evident moderate level of anaemia in adult goats. The main risk factors responsible for the prevalence and distribution of gastrointestinal parasites in goats were physical location of the farm, production systems and frequent use of anthelmintics. Therefore, a comprehensive farmers' awareness programme is imperative to build resilient marginalized smallholder farming communities through access to information, knowledge, gender responsive climate smart technologies and adaptive management practices. Further studies ought to be undertaken to establish the socioeconomic impact associated with gastrointestinal parasites in goat production.

\section{Acknowledgement}

The authors would like to appreciate the staff of the Department of Agriculture and Biological Sciences, Uganda Christian University for their support and guidance. 


\section{References}

Akhtar, M.S., Iqbal, Z., Khan, M. N. and Lateef, M.2000. Anthelmintic activity of medicinal plants with particular reference to their use in animals in the Indo Pakistan subcontinent. Small Ruminant Research 38: 99-107.

Babjak, M., Konigova, A., Urda-dolinská, M. and Várady, M. 2017. Gastrointestinal helminthes infections of dairy goats in Slovakia. Helminthologia 54(3): 211 - 217. DOI 10.1515/helm2017-0027.

Beveridge, I., Pullman, A. L., Martin, R.R. and Barelds, A. 1989. Effects of temperature and relative humidity on development and survival of the free-living stages of Trichostrongylus colubriformis, T. rugatus and T. vitrinus. Veterinary Parasitology 33(2):143-153. Doi: 10.1016/0304-4017(89)90062-9.

Dagnachew, S., Amamute, A. and Temesgen, W. 2011. Epidemiology of gastrointestinal helminthiasis of small ruminants in selected sites of North Gondar zone, Northwest Ethiopia. Ethiopan Veterinary Journal 15 (2): 57-68.

Duncan, J. R. and Prasse, K.W.1986. Veterinary laboratory medicine-clinical pathology (Ed 2). Ames, IA, Lowa State University Press.

Hansen, J. 1994. The Epidemiology, Diagnosis and Control of Helminthes Parasites of Ruminants. Animal Production and Health Division Food and Agriculture Organization Rome, Italy.

Iglesias, L. E., Saumell, C.A. and Fernández, A. S. 2006. Environmental impact of ivermectin excreted by cattle treated in autumn on dung fauna and degradation of faeces on pasture. Parasitology Research 100 (1).

Jiregna, D., Abdela, H., Abriham, K. and Chala, M. 2018. Prevalence and Associated Risk Factors of Gastrointestinal Nematodes of Sheep and Goats in Ziway Dugda District, Eastern Arsi Zone of Oromia Regional State, Ethiopia. Journal of Animal and Veterinary Sciences 4(2): 614. http://dx.doi.org/10.20431/2455-2518.0402002.

Kantzoura, V., Kouam, M. K., Theodoropoulou, H., Feidas, H. and Theodoropoulos, G.2012. Prevalence and Risk Factors of Gastrointestinal Parasitic Infections in Small Ruminants in the Greek Temperate Mediterranean Environment. Journal of Veterinary and Animal Science 2: 25-33, https://doi.org/10.4236/ ojvm.2012.21005.

Katali, K. B., Ampaire, A., Komungyeyo, J., Mukiibi, R., Masembe, C., Onzima, R. 2015. Efficacy of Commercially Available Anthelmintics in Controlling Gastrointestinal Nematodes in Goats Managed Under Natural Conditions in the South Western Highlands of Uganda. American Journal of Clinical and Experimental Medicine 3(6): 355-363.

Khodakaram, T. and Hashemnia, M. 2017.An overview of intestinal coccidiosis in sheep and goats 167: 1-2, 9-20

Kramer, J. W. 2000. Normal haematology of cattle, sheep and goats. In Schlam's veterinary Haematology (Ed5), Philadelphia

Lisa, C., Vreni Jean, R., Abbani, A. A., Ngandolo, B. G., Helena, G. J., Hattendorf, J., Esther, S. and Jakob, Z. 2014. Prevalence of Fasciola gigantica infection in slaughtered animals in south-eastern Lake Chad area in relation to husbandry practices and seasonal water levels. Veterinary Research 10: 81, https://doi.org/10.1186/1746-6148-10-81.

MAFF.1986. Manual of Veterinary Parasitological Laboratory Techniques, Fisheries and Food Ministry of Agriculture, HMSO, London. Reference Book, Vol. 418.

Magona, J. W. and Musisi, G.2002. Influence of age, grazing system, season and agroclimatic zone on the prevalence and intensity of gastrointestinal strongylosis in Ugandan goats. Small Ruminant Research 44:187-192. 
Martinez, S.R., Santos, P.A., Fernández, F. N., Domenech, C., Rodríguez, M. and Rodríguez, Z. G. 2015. Prevalence and Risk factors of intestinal parasitic infestation in Rural Community. Consola Municipality Cuba 63(4):333-339. Doi: 10.7727/wimj.2013.103.

Meingi, N., Gichigi, M. N. and Njoroge, G. K.2001. Gastrointestinal nematode infection in sheep grazing on communal land in Nyandarua District of Central Kenya in relation to deworming practice. Bulletin of Animal Health Production (Africa) 49: 153-161.

Nabukenya, I., Rubaire-Akiiki, C., Olila, D., Muhangi, D., and Höglund, J. 2014. Anthelmintic resistance in gastrointestinal nematodes in goats and evaluation of FAMACHA diagnostic marker in Uganda. Veterinary Parasitology 205 (3-4): 666-75.,

Negasi, W., Bogale, B. and Chanie, M.2012. Prevalence, Species Composition and Associated Risk Factors in and Around Mekelle Town, Northern Ethiopia. European Journal of Biological Sciences 4 (3): 91-95. Doi: 10.5829/idosi.ejbs.2012.4.3.65149.

Nganga, C.J., Maingi, N., Kanyari, P.W.N. and Munyua, W. K. 2004. Gastro intestinal nematode infections in Dorper lambs in a semi-arid area of Kajiado District of Kenya. Bulletin of Animal Health and Production Africa 52: 160-166.

Nsereko, G., Emudong, P., Mulindwa, H. and Okwee-Acai, J. 2015. Prevalence of common gastro- intestinal nematode infections in commercial goat farms in Central Uganda. Uganda Journal of Agricultural Sciences 16 (1): $99-106$.

Nwigwe, J.O., Njoku, O.O., Odikamnoro, O.O. and Uhuo, A.C.2013. Comparative study of intestinal helminths and protozoa of cattle and goats in Abakaliki metropolis of Ebonyi State, Nigeria. Advances in Applied Science Research 4: 223-227.

Nwosu, C., Madu, P. and Richards, W.2007. Prevalence and seasonal changes in the population of gastrointestinal nematodes of small ruminants in the semi-arid zone of north-eastern Nigeria. Veterinary Parasitology 144(1): 118-124.

Ratanapob, N., Arunvipas, P., Kasemsuwan, S., Phimpraphai, W., Panneum, S. 2012. Prevalence and risk factors for intestinal parasite infection in goats raised in Nakhom Pathom Province, Thailand. Tropical Animal Health Production 44: 741-745.

Ruiz, A., Behrendt, J.H., Zahner, H., Hermosilla, C., Pérez, D., Matos, L., Muñoz, M.C., Molina, J.M. and Taubert, A. 2010. Development of Eimeria ninakohlyakimovae in vitro in primary and permanent cell lines. Veterinary Parasitology 173: 2-10.

Sheikh, B. A. 2016. Seasonal Prevalence of Gastro-Intestinal Helminths of Sheep (Ovis Aries) and Goat (Capra Hircus) with Respect to Age and Gender. Journal of Animal Science Advances. DOI: $10.5455 /$ jasa.20160409122017.

Shivairo, R.S. and Musala, L.M.2002. The Significance of Strongylosis in Small Ruminants in Pastoral Systems: The Case of Boringo District. Bulletin Animal Health Production Africa 50: 126-129.

Silverman, P.H. and Patterson, J.E. 1962.Histotrophic (Parasites) stages in Haemonchus contortus. Nature (London) 185: 54-55.

Singh, E., Kaur, P., Singla, L.D. and Bal, M.S. 2017. Prevalence of gastrointestinal parasitism in small ruminants in western zone of Punjab, India. Veterinary World 10(1): 61-66.

Singh, V., Varshney, P., Dash, S. and Lal, H. 2013. Prevalence of gastrointestinal parasites in sheep and goats in and around Mathura, India. Veterinary World 6(5): 260-262.

Solaiman, S.G. 2010. Goat science \& production. $1^{\text {st }}$ Ed. Singapor. Wiley. Black well.

Thornton, P.K. 2010. Livestock production: recent trends, future prospects. Nairobi Kenya Philosophical Transductions of the Royal Society of London. Biological Sciences 365(1554): 2853-2867

Thrushfield, D. M. 1995. Veterinary Epidemiology. Blackwell Science. 
UBOS.2018. National Population and housing census 2014- area specific profiles Series. Kampala- Uganda.

Zvinorova, P.L., Halimani, T.E., Muchadeyi, C., Matika, O., Riggio, V. and Dazama, K.2016. Prevalence and risk factors of gastrointestinal parasitic infections in goats in low-input lowoutput farming systems in Zimbabwe. Small Ruminant Research 75-82,143. https://doiorg/10.1016/j.smallruminant.2016.09.005. 